\title{
Scotosensitive myoclonic seizures in MERRF
}

自

Figure EEG revealing eye-closure-induced bioccipital spike-and-wave discharges

A

App1-F3

F3-C3

C3-P3

P3-01

Fp2-F4

$\mathrm{F} 4-\mathrm{C} 4$

C4-P4

P4-02

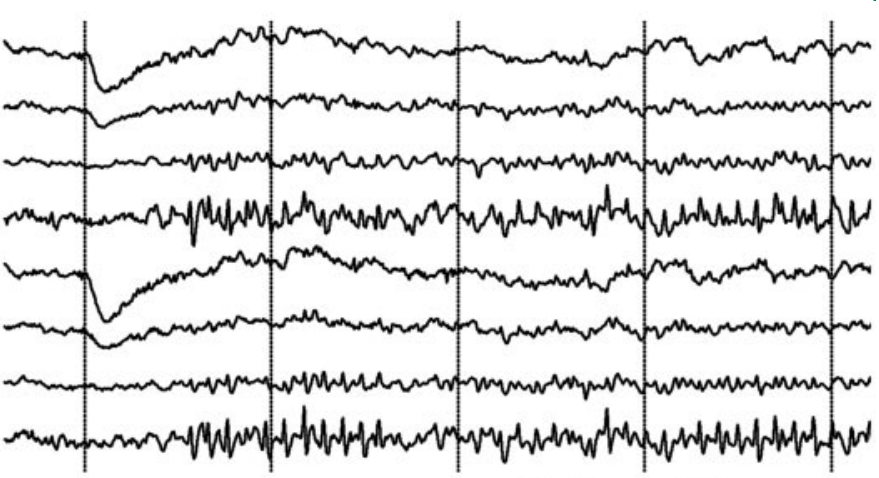

$50 \mu \mathrm{V}$

$1 \mathrm{Sec}$.

B

C
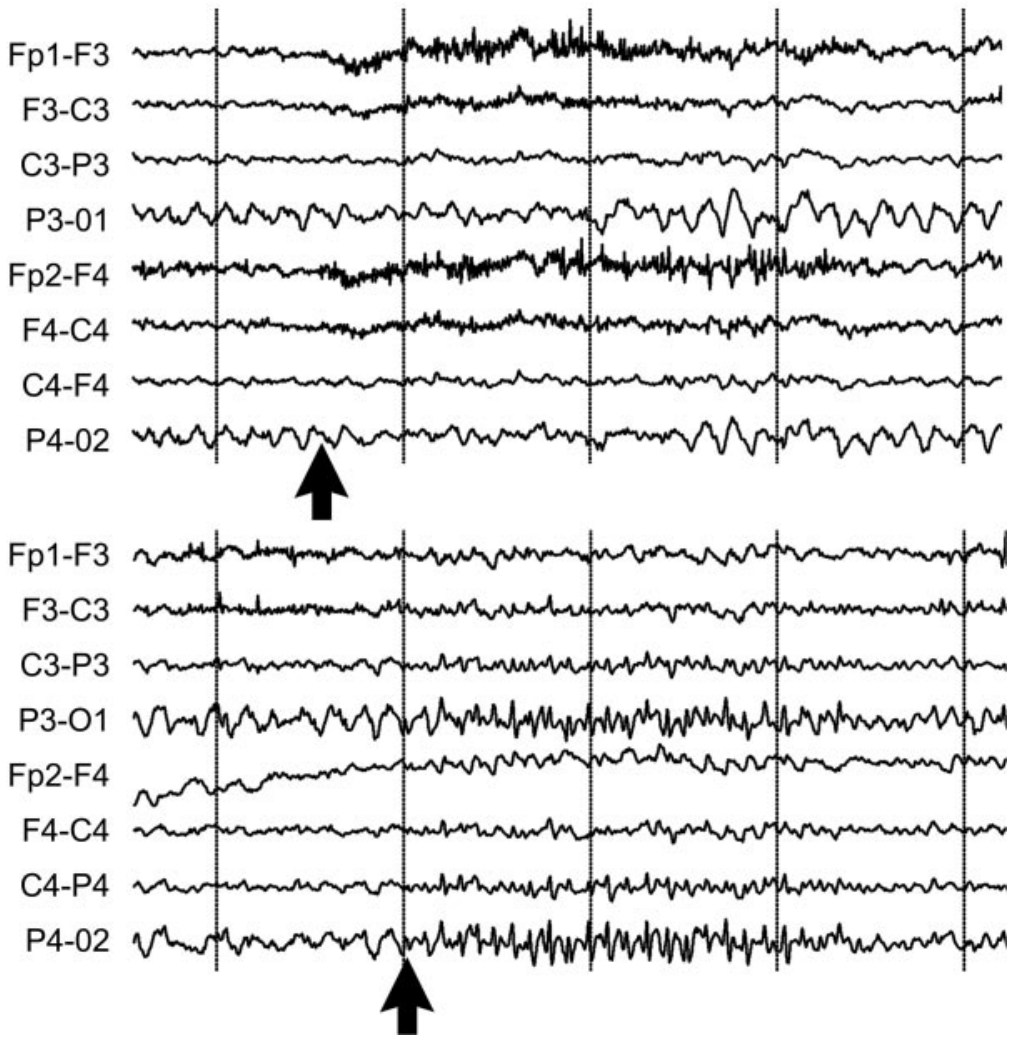

Eye-closure-induced bioccipital spike-and-slow wave activity at approximately $10 \mathrm{~Hz}(\mathrm{~A})$ was frequently associated with bilateral arm myoclonus. Attempting to close eyes against enough resistance to keep them open did not elicit such a pattern ( $B$, arrow), whereas preventing the light from entering the eyes, with the eyes still open, triggered the ictal discharge ( $\mathrm{C}$, arrow).

Supplemental data at

www.neurology.org
A 42-year-old woman presented with a history of intractable eye-closure-sensitive myoclonic and grand mal seizures since age 22, resulting in falls and fractures. She also had five episodes of status epilepticus. She denied visual phenomena, eyelid myoclonus, and absence seizures. She had normal cognitive function, but proximal muscle weakness of all extremities. Her EEG revealed eye-closure-induced bioccipital spike-and-wave discharges. These were scotosensitive, ${ }^{1}$ i.e., induced by lack of visual input, but not by eyelid closure (figure and video [on the Neurology ${ }^{\circledR}$ Web site at www.neurology.org]). Intractability, late age at onset, and complications are unusual features of eye-closure-induced seizures, and the concomitant muscle weakness suggested mitochondrial disease. ${ }^{2}$ Mitochondrial DNA analysis identified the myoclonic epilepsy associated with ragged red fibers-associated A8296G mutation in the tRNA(Lys) gene.

Mohamad Z. Koubeissi, MD, Chaiyos Khongkhatithum, $M D$, Annette I. Janus, $M D$, and Hans Lïders, $M D, P h D$, Cleveland, $\mathrm{OH}$

Disclosure: The authors report no disclosures.

Address correspondence and reprint requests to Dr. Mohamad Z. Koubeissi, Department of Neurology, University Hospitals Case Medical Center, Case Western Reserve University, 11100 Euclid Avenue, Cleveland,OH 44106-5040; mohamad.koubeissi@uhbospitals.org

\section{ACKNOWLEDGMENT}

The authors thank Maha Haddad and Doris Evans for assistance in preparing the video.

\section{REFERENCES}

1. Gastaut H, Tassinari CA. Triggering mechanisms in epilepsy: the electroclinical point of view. Epilepsia 1966;7: 85-138.

2. Garcia Silva MT, Aicardi J, Goutieres F, Chevrie JJ. The syndrome of myoclonic epilepsy with ragged-red fibers: report of a case and review of the literature. Neuropediatrics 1987;18:200-204. 


\title{
Neurology
}

\author{
Scotosensitive myoclonic seizures in MERRF \\ Mohamad Z. Koubeissi, Chaiyos Khongkhatithum, Annette I. Janus, et al. \\ Neurology 2009;72;858 \\ DOI 10.1212/01.wnl.0000343959.15205.52
}

This information is current as of March 2, 2009

\section{Updated Information \& Services \\ Supplementary Material \\ References \\ Subspecialty Collections}

Permissions \& Licensing

Reprints including high resolution figures, can be found at: http://n.neurology.org/content/72/9/858.full

Supplementary material can be found at: http://n.neurology.org/content/suppl/2009/03/02/72.9.858.DC1

This article cites 2 articles, 0 of which you can access for free at: http://n.neurology.org/content/72/9/858.full\#ref-list-1

This article, along with others on similar topics, appears in the following collection(s):

EEG

http://n.neurology.org/cgi/collection/eeg_

Epilepsy semiology

http://nn.neurology.org/cgi/collection/epilepsy_semiology

Muscle disease

http://n.neurology.org/cgi/collection/muscle_disease

Myoclonus; see Movement Disorders/myoclonus

http://n.neurology.org/cgi/collection/myoclonus_see_movement_disord ers-myoclonus

Information about reproducing this article in parts (figures,tables) or in its entirety can be found online at:

http://www.neurology.org/about/about_the_journal\#permissions

Information about ordering reprints can be found online:

http://n.neurology.org/subscribers/advertise

Neurology ${ }^{\circledR}$ is the official journal of the American Academy of Neurology. Published continuously since 1951, it is now a weekly with 48 issues per year. Copyright . All rights reserved. Print ISSN: 0028-3878. Online ISSN: 1526-632X.

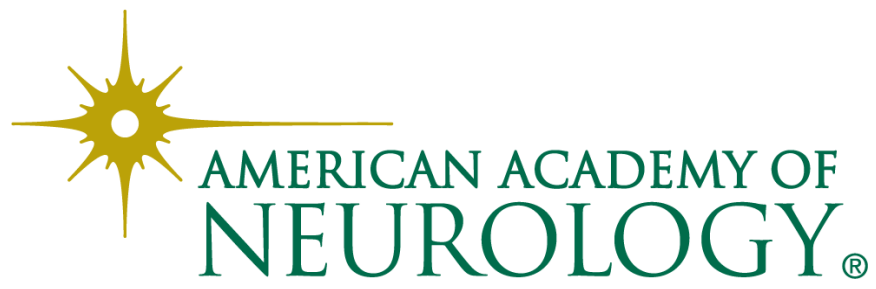

